\title{
How specific is apprenticeship training? Evidence from inter-firm and occupational mobility after graduation
}

\author{
By Barbara Mueller ${ }^{a}$ and Jürg Schweri ${ }^{b}$ \\ aUniversity of Bern, Institute of Sociology, Project TREE, Fabrikstrasse 8, 3012 Bern, Switzerland; \\ e-mail: barbara.mueller@soz.unibe.ch \\ ${ }^{\text {b}}$ Swiss Federal Institute for Vocational Education and Training, Kirchlindachstrasse 79, 3052 \\ Zollikofen, Switzerland; e-mail: juerg.schweri@ehb-schweiz.ch
}

\begin{abstract}
Do apprenticeships convey mainly general or also firm- and occupation-specific human capital? Specific human capital may allow for specialization gains, but may also lead to allocative inefficiency due to mobility barriers. We analyse the case of Switzerland, which combines a comprehensive, high-quality apprenticeship system with a lightly regulated labour market. To assess human capital transferability after standardized firm-based apprenticeship training, we analyse inter-firm and occupational mobility and their effects on post-training wages. Using a longitudinal data set based on the PISA 2000 survey, we find high inter-firm and low occupational mobility within one year after graduation. Accounting for endogenous changes, we find a negative effect of occupation changes on wages, but no significant wage effect for firm changes. This indicates that occupation-specific human capital is an important component of apprenticeship training and that skills are highly transferable within an occupational field.
\end{abstract}

JEL classifications: C25, J24, J31, J62

\section{Introduction}

In this article, we study the specificity and transferability of human capital by analysing inter-firm and occupational mobility of Swiss apprentices shortly after the conclusion of training. Countries with comprehensive work-based apprenticeship programs lend themselves to the study of occupation-specific human capital because they are structured along a multitude of well-defined occupations and corresponding educational tracks. Work-based apprenticeships are of central importance to the educational system in many countries, such as Austria, Denmark, Germany, the Netherlands, and Switzerland (Wolter and Ryan, 2011). In the UK, policy initiatives have been proposed to reinvigorate the apprenticeship system (see UK Parliament, 2009), whilst calls for more vocational education tracks are a 
subject of public debate in the USA (see Hoffman, 2011; Symonds et al., 2011; or President Barack Obama's 2014 State of the Union Address).

The main economic rationale for a comprehensive work-based apprenticeship system is to provide trainees with a set of clearly defined and nationally tested occupational skills that are transferable to other firms after graduation. Occupational skills promise specialization gains due to more specialization than would be achieved in a purely general education system. Apprentices acquire occupation-specific human capital that enables them to immediately begin work as skilled workers after training; in a general education system, they would need to go through a period of on-the-job training when taking up employment at a firm. However, this specialization may also be detrimental if the allocative efficiency of apprenticeship systems is inferior to that of general education systems. Specific human capital may impede workers from making efficiency-enhancing firm or occupation changes and lead to wage losses for those who want to or have to leave the training firm or the learned occupation. This barrier becomes particularly important when job prospects on the labour market deteriorate because of the business cycle or changes in the skills needed in the economy, due to technological change or macroeconomic reallocation (Wasmer, 2006; Bassanini et al., 2007). Transferability might become even more important in the future, as some studies have indicated that occupational mobility has generally been increasing in recent decades (Parrado et al., 2007; Kambourov and Manovskii, 2008; Lalé, 2012).

The potential for gains from specialization as well as allocative inefficiencies associated with apprenticeship systems depend on the transferability of the human capital acquired in apprenticeships. Firm-based apprenticeships have been suspected of conveying an overly specific, narrow set of skills. ${ }^{1}$ To empirically assess the transferability of this human capital, we study the incidence of inter-firm and occupational mobility ${ }^{2}$ of Swiss apprentices shortly after their training and the effect of these types of mobility on wages.

The literature on mobility after apprenticeships refers mainly to Germany and comes to heterogeneous results on the importance of inter-firm mobility for wages. Von Wachter and Bender (2006) found causal evidence of initial wage losses for graduates leaving middleand large-sized training firms at the time of graduation. In addition, they showed that initial sorting, adverse selection, and endogenous job mobility bias ordinary least squares (OLS) regression results such that short-run wage losses are under-estimated on average. Acemoglu and Pischke (1998) and Bougheas and Georgellis (2004) also found negative effects of leaving the training firm. Harhoff and Kane (1997) and Werwatz (1996) found some evidence for positive wage effects, whereas Dustmann et al. (1997) and Euwals and Winkelmann (2004) found no significant mover-stayer wage differential.

The effects reported for switching out of the learned occupation are similarly heterogeneous. Gathmann and Schoenberg (2010) found that task-specific human capital accounts for a part of the wage growth observed for medium-skilled workers. Fitzenberger and Spitz (2004) found positive effects of occupational changes. Werwatz (2002) found wage losses only for those occupational movers who ended up in unskilled jobs, showing that apprentices' human capital is largely general. Clark and Fahr (2002) came to a similar conclusion. Goeggel and Zwick (2012) looked at firm and occupation changes in the period

1 Heckman (1994) described the German apprenticeship program as 'very narrow technical training' with a 'rigid curriculum' that contributes 'to diminished options in later life'.

2 We use the terms 'occupational change' and 'occupational mobility' interchangeably. 
immediately after graduation and reported heterogeneous wage effects; on average, they found positive effects for firm changes and negative effects for occupation changes.

We contribute to this literature by analysing firm and occupation changes in one estimation model. Many of the mentioned studies addressed the endogenous nature of mobility, but none of them analysed employer and occupation changes simultaneously. ${ }^{3}$ This is necessary to disentangle the effects of firm- and occupation-specific human capital on wages in the early careers of apprenticeship graduates, because occupational change typically goes hand in hand with employer change. A new study by Fitzenberger et al. (2015), however, uses an estimation approach similar to ours for Germany. They use variation in regional labour market characteristics to analyse wage effects caused by both mobility across firms and mobility across occupations after graduation from apprenticeship. They find that pure firm changes and occupation-and-job changes result in average wage losses.

The evidence reported in the literature may not be generalizable outside of Germany, where there are labour market institutions that limit the ability to observe the effects of mobility on wages (Muehlemann et al., 2010). Labour market institutions that hinder posttraining mobility (such as work councils, industry-wide collective agreements, strong employment protection) are weaker or non-existent in Switzerland. By looking at outcomes in Switzerland, we can shed light on the outcomes of mobility from comprehensive apprenticeships schemes (like those in Germany) under more lightly regulated labour market conditions, similar to those that prevail, for example, in English-speaking countries. ${ }^{4}$

We investigate the inter-firm and occupational mobility of a sample of apprentices who have just completed several years of training in firms (combined with vocational school) in a particular occupation. After training, apprentices must decide whether to (i) continue working for their training firm as a skilled worker, (ii) change firms within the learned occupation, or (iii) change firms and move out of the learned occupation. ${ }^{5}$ Analysing the causal wage effect of trainees' mobility decisions by addressing the endogeneity of mobility allows us to assess the transferability of the trainees' newly acquired human capital to other firms and occupations.

We use a longitudinal data set that is based on the Swiss cohort of the Programme for International Student Assessment (PISA) 2000 and matches employer and employee data. We exploit the employment information of workers one year after apprenticeship graduation, along with information on their training period. One advantage of this data is that all trainees are at the same stage of their labour market career; mobility immediately after training is not

3 Von Wachter and Bender (2006) and Werwatz (1996) dropped occupational changers when analysing the causal wage effect of employer changes. Clark and Fahr (2002) focussed on displaced workers when analysing occupational changes. Goeggel and Zwick (2012) estimated separate models for employer change and occupational change; it remains unclear whether the correlation between them is taken into account. Other studies ignored the possibility that the wage effect of firm (occupation) changes might be partly driven by a loss of occupation-specific (firm-specific) human capital. An exception is Longhi and Brynin (2010), who studied inter-firm and occupational mobility in Britain and Germany but did not address the endogeneity of mobility with respect to wages.

4 The Swiss labour market is one of the least regulated in Europe. Unlike in Germany, employment protection is low (OECD, 2004; Venn, 2009) and inter-firm mobility after apprenticeship is relatively high (Wolter and Ryan, 2011).

5 We restrict attention to these three alternatives. Occupation change always implies a firm change since we observe virtually no cases of occupation changes within the training firm after training. 
influenced by years of (additional) labour market experience. Some confounding factors associated with years on the labour market include job-shopping, multiple changes, and internal promotions. By avoiding these factors, the wage effects of mobility after training provide a "purer" measure of the transferability of human capital acquired in training than analyses that compare learned and current occupations for employees with many years of labour market experience. ${ }^{6}$ Furthermore, the data set contains open text information on the learned and current occupations (in addition to occupation codes) that we use to ensure accurate coding of occupation change. The wealth of background variables available in PISA allows us to control for important dimensions of individual heterogeneity such as socio-economic background, ability, and the quality of worker-firm and worker-occupation matches. Finally, we address further sources of endogeneity of inter-firm and occupational mobility by means of the multinomial treatment regression model of Deb and Trivedi (2006).

\section{Human capital production in Swiss apprenticeships}

Two thirds of a cohort in Switzerland undertake a firm-based apprenticeship at the upper secondary level, whereas only approximately $20 \%$ of a cohort choose college-bound high school (CCRE, 2014). The quality of this mass apprenticeship system is considered to be very high (Hoeckel et al., 2009; Hoffman, 2011). Swiss apprenticeships should not be confused with remedial education or training for the unemployed. This is highlighted by the fact that Switzerland's open and highly competitive economy relies on a skilled workforce that has to a large extent been trained in apprenticeships.

Swiss youngsters enter the apprenticeship market and apply for training places at firms after compulsory schooling. Firms are free to offer training places in any of approximately 250 training occupations covering all domains of the economy and to select the apprentices they want to take on. Cantonal authorities have to approve apprenticeship contracts to ensure that training firms fulfil the legal requirements (such as employing trained supervisors). Whilst participation in the apprenticeship market is voluntary for firms and youngsters, federal laws regulate the occupations in which apprenticeships can be undertaken and provide various instruments for quality control. National training ordinances define every occupation's title, duration, educational objectives, curricula (including the number of lessons in vocational school), and procedures for the final exams. These regulations and the external certification reduce asymmetric information between the actors about training content and workers' ability (Acemoglu and Pischke, 2000; Malcomson et al., 2003) and ensure that firms provide a certain amount and quality of training that is transferable to other firms after graduation.

Whilst the state fully finances vocational schools, training firms receive no subsidies. Cost-benefit surveys show that training firms incur substantial costs for on-the-job trainers, infrastructure, material, and so on. Yet the productivity of apprentices during the training period offsets all costs for the firms on average (Wolter et al., 2006). This result is in line with the standard Becker (1962) model for general on-the-job training in competitive labour markets, where trainees bear the costs of general training.

6 Firm or occupation movers may require more time than stayers before their wages reflect their individual performance potential. Firms would then pay wages equal to the expected value of movers' productivity, which will still allow us to identify the productivity differential between movers and stayers. 
Successful graduates of an apprenticeship are awarded federally recognized diplomas and the respective titles that identify them as skilled workers in their occupation. The apprenticeship curricula provide for a mix of general and specialized occupational skills: for three or four years (in few cases, two years), apprentices work for three to four days a week in their training firm and attend vocational school for one to two days a week. In firms, they acquire all types of skills, learning about the firm's products and production technology, occupational tasks, and general skills such as work values (accuracy, etc.). In vocational schools, apprentices attend general education classes and occupation-specific lessons. Industry training courses organized by employer associations complement the education in schools and firms by training all apprentices in a set of occupation-related skills defined in the training ordinance. Final exams consist of oral, written, and practical parts that test general and occupational knowledge and skills as defined in the training ordinance.

From a human capital perspective, apprentices acquire a mix of general and occupational skills that are transferable to other firms. Firms are free to provide additional firm-specific skills. Stevens (1994) demonstrates that monopsony power due to imperfect competition can lead training firms to over-invest in the firm-specific element of training to reduce turnover and capture the benefits of training at the expense of the worker. If the costs and benefits of firm-specific human capital are shared between training firm and apprentice (Becker, 1962; Hashimoto, 1981; Leuven and Oosterbeek, 2001), the workers' returns on firm-specific human capital should be observable in wages. Changing the employer after training should then lead, ceteris paribus, to a wage loss.

Becker's (1962) concept of firm-specific human capital extends to occupation-specific human capital (Shaw, 1987; Zangelidis, 2008; Kambourov and Manovskii, 2009; Sullivan, 2010): occupation-specific human capital is transferable to other jobs within the same occupation but cannot be used in jobs outside that occupation. It can thus be classified as 'transferable' according to the definition by Stevens (1994), in which 'it is of some value to at least one firm in addition to the training firm', but not perfectly general. ${ }^{7}$ An exogenous change away from the learned occupation should entail a wage loss, ceteris paribus, because acquired occupation-specific skills cannot be put to use anymore. The causal wage difference between those changing occupation and those staying in an occupation can be interpreted as a measure of the transferability of training and, accordingly, as a measure of the occupation-specificity of the human capital that the training confers.

\section{Data}

We use the Swiss TREE (Transition from Education into Employment) data set, which is a follow-up survey of pupils that were tested at age 15 by PISA 2000 (OECD, 2002). As of 2001, TREE followed the students tested in PISA 2000 (then in their last year of compulsory schooling) for several years thereafter (TREE, 2008; Bertschy et al., 2009). These data enable us to obtain PISA reading literacy test scores and other background information on individuals, along with detailed information about their training and working careers on a yearly basis. Sample attrition is relatively low at approximately $6.5 \%$ per year. We use individuals who completed their apprenticeship by 2005 and use data including wave 2006 to

7 At first sight, such transferable human capital does not offer a lever for firms to retain workers as firm-specific human capital does. Yet if firms have monopsony power within the boundaries of the occupation, occupation-specific skills could also be used to retain workers (Smits, 2007). 
identify their subsequent labour market outcome one year after graduation. Focussing on this period allows us to include the vast majority of the individuals with apprenticeships because these programmes typically start immediately after compulsory school and end after two to four years. ${ }^{8}$ We observe 1,618 individuals with a transition from apprenticeship to work or to another activity within a year after graduation. Of the graduates, $72 \%$ took up work, $15 \%$ were enrolled in further education, $4 \%$ were serving in the military, $3 \%$ were temporarily out of the labour force because they were travelling or engaged in language studies abroad, and $6 \%$ were unemployed. We include working individuals with non-missing values in the wage and mobility variables. Our final sample of employed individuals include 878 observations for the wage regressions. Due to the limited sample size, we do not split the sample between men and women. Female labour participation is similar to male participation at this age for apprenticeship graduates. ${ }^{9}$ We control for occupation dummies to account for occupational segregation by gender in the labour market.

The mobility behaviour after apprenticeship is our primary interest; firm change is defined as working in a different enterprise than the training enterprise. ${ }^{10}$ Occupation change is defined as a change away from the apprenticeship two-digit occupation after the apprenticeship period, based on occupation codes used to classify occupation by the Swiss Federal Statistical Office (FSO). ${ }^{11}$ There are 39 two-digit occupation categories. Thus, we adopt a rather broad definition of an occupation to exclude changes between occupations entailing a very similar set of skills. ${ }^{12}$ As a sensitivity check, we also provide results for five-, three-, and one-digit changes. The Online Appendix contains detailed information on our use of the occupational classifications and open text information from the surveys to obtain valid coding of occupational change. As only three individuals showed an occupation change without a firm change (these were dropped from the analysis), we defined three mutually exclusive mobility categories. These are represented by the two dummy variables: firm movers who remain within the learned occupation, occupation changers who switched both firm and occupation, and the reference category, stayers.

8 Comparing our TREE sample with official numbers on apprenticeship graduates, graduates of four-year apprenticeships are slightly under-represented.

9 In our data, female labour market participation of apprenticeship graduates is even higher $(77 \%$ versus $66 \%$ ). Whilst both genders show very similar rates of unemployment $(6 \%)$ and periods of being temporarily out of the labour force because they were travelling or engaged in language studies abroad $(3 \%)$, only male participants are in military service $(9 \%)$. The proportion of graduates who attend further certifying education (e.g., a university of applied sciences) is slightly higher for male graduates as well ( $16 \%$ versus $14 \%)$.

10 Enterprises can consist of several establishments in the definition of the Federal Statistical Office (FSO). We use information from the firm census of the FSO to identify changes on enterprise level. This is our preferred definition because information on workers' abilities is likely to be available to the enterprise, not only to the establishment; see Euwals and Winkelmann (2004) for a short discussion.

11 Note that industry changes occur almost exclusively together with occupation changes in our data. Because all apprenticeship regulations refer to clearly defined occupations and not to industries, occupations are the relevant dimension in our context.

12 Task-based (Gathmann and Schoenberg, 2010) or skill-weights approaches (Lazear, 2009; Geel et al., 2011) allow one to analyse the distance between occupations directly. The more classical approach that distinguishes amongst official occupations remains relevant because all state regulations (on training ordinances, curricula, and diplomas) are based on these. 
In our estimations, we always include variables on personal characteristics (gender, immigrant), parental education, language region, the apprenticeship training program (occupation and duration of apprenticeship, size of training firm), information on the period between end of apprenticeship and time of interview, size of the current firm, and the unemployment rate in the occupation. ${ }^{13}$ Further variables (ability and match quality proxies) are discussed in the next section. Online Appendix Table A1 contains variable definitions, and Table A2 presents descriptive statistics for all variables.

\section{Estimation strategy}

\subsection{Operationalization of the hypotheses}

To estimate the effects of firm-specific and occupation-specific components of human capital, we analyse the wage effects of changing firm within occupation (firm movers) and changing firm across occupation (occupation changers), as opposed to staying in the training firm and the occupation (stayers). These wage differentials can, in principle, be estimated by an OLS log wage $\left(\ln w_{i}\right)$ regression for person $i$ :

$$
\ln w_{i}=\beta^{0}+\beta^{f m} f m_{i}+\beta^{o c} o c_{i}+x_{i} \beta^{x}+u_{i}
$$

Our main hypotheses pertain to the wage effect of mobility. ${ }^{14}$ Due to human capital losses, we expect the coefficients $\hat{\beta}^{f m}$ and $\hat{\beta}^{o c}$ for the firm mover $(f m)$ and occupation changer $(o c)$ dummy variables to be negative, with a larger wage loss for occupation changers than for firm movers. $x$ is a vector of covariates, and $u$ is the error term.

\subsection{Potential sources of bias in OLS estimation}

The OLS dummy coefficients may be biased due to four reasons: (i) heterogeneous occupation changes, (ii) optimizing behaviour in job search, (iii) heterogeneity in worker-firm and worker-occupation matches, and (iv) heterogeneity in worker ability. We discuss the likely direction of the biases introduced in OLS estimation, as well as our strategy to address these endogeneity issues.

First, the transferability of human capital from one occupation to another may not be constant. For instance, an electrician might still make some use of his technical skills as a car mechanic, but not as an office clerk. Thus, we would like the OLS coefficient of the occupational change dummy in eq. (1) to identify the mean loss of human capital between two different occupations due to occupation-specific human capital. It does not identify a mean effect if occupation changers are more likely to choose a new occupation that allows a high transfer of human capital from their learned occupation. In this case, occupation

13 Brunner and Kuhn (2014, and others cited therein) have shown that unemployment at the time of labour market entry has a substantial effect on individuals' wages.

14 Goeggel and Zwick (2012) used the wage 'mark-up' between the last apprenticeship wage and the first skilled wage as dependent variable, arguing that higher quality training firms pay higher apprenticeship wages. However, human capital theory predicts that trainees accept lower training wages in return for receiving general human capital. Lower wages might thus indicate a higher training intensity. Muehlemann et al. (2013, table 3) indeed find that Swiss firms whose staff provides more training hours to trainees pay lower apprenticeship wages. The wage mark-up is then not suited to measure human capital transferability. Instead, we include apprenticeship wage as control in our robustness checks. 
changers transfer more of their skills than would be the case if changes were purely random. The OLS coefficient for occupation change will be biased upwards and under-estimate the wage penalty for changing occupation.

Second, apprentices have to search for jobs as their apprenticeship contracts end. In search theory (Mortensen, 1986; Rogerson et al., 2005), the focus lies on the endogenous nature of inter-firm and occupational mobility with respect to wages. Search theory assumes that workers trade off the gains from accepting a job that offers a given wage with the expected gains from continuing to search and waiting for a higher wage offer. Apprentices will search for a post-training job and compare wage offers from the training firm, from other firms within the same training occupation and from firms in other occupations altogether. Occupational or inter-firm changes are realized when the wage offer in another firm or occupation exceeds the asking wage of the graduating apprentices. Because voluntary changers tend to benefit from mobility, their wage loss due to specific human capital will be under-estimated.

Third, during the period of training, apprentices experience the quality of their match with the training firm and with the occupation. Matching theory (Jovanovic, 1979) highlights the idea that job mobility enhances efficiency when it improves the quality of worker-firm or worker-occupation matches. Apprentices might thus voluntarily change firm or occupation after training to dissolve a bad match. It is unclear whether these apprentices will have a higher or lower average match quality after their change than stayers and whether match quality introduces any bias. Stevens (2003) convincingly argues that stayers will have belowaverage matches that they do not resolve because they would lose firm-specific returns. In the presence of returns to specific human capital, match quality differences might thus introduce an upwards bias in the OLS coefficients for the firm mover and occupation changer dummies. We would under-estimate the wage loss due to specific human capital.

Fourth, the literature suggests that mobility in the labour market depends on the unobserved ability of individuals. If abler apprentices receive better offers from outside firms, selection into mobility could be positive. However, the predominant case discussed in the literature is adverse selection. Gibbons and Katz (1991) analysed adverse selection in job changes when the ability of individuals is not observable by outside employers. In the model developed and tested by Acemoglu and Pischke (1998), apprenticeships serve as screening devices for firms to learn about the most able apprentices and retain them after graduation, whilst not retaining those who fail to attain a certain ability threshold. This leads to involuntary mobility of adversely selected graduates. In such a case, OLS over-estimates the wage penalty for changers, as firm and occupation changers are less able on average.

The first three of the four sources of endogeneity discussed are presumed to induce an upwards bias in the OLS regression estimates of our mobility dummy variables, which results in under-estimation of the wage loss that would occur when an apprentice moves randomly (in a thought experiment) from one occupation or firm to another. If the size of a (fourth) possible bias due to ability sorting is small compared to the size of the other biases discussed, then OLS regression provides a lower bound for the causal wage penalty resulting from firm and occupation changes and hence for the returns to specific human capital.

\subsection{Estimation set-up}

Our first estimation model for eq. (1) is OLS regression, augmented with observable proxy variables to account for some of the possible sources of bias. The second 
type of models are endogenous treatment regressions that account for the endogeneity problems.

According to the third and fourth sources of endogeneity discussed in the preceding section, the $f m$ and $o c$ dummy variables depend on individuals' unobserved abilities and match qualities in a sample with endogenously determined firm and occupation changes. With respect to ability, we control for individuals' grades in the final examination at the end of apprenticeship training, reading literacy test scores at age 15 (before training) from the international PISA 2000 survey, ${ }^{15}$ PISA mathematical self-concept, self-efficacy in work tasks during apprenticeship, extrinsic motivation, vocational baccalaureate, and previous school type on lower-secondary level. This proxy solution assumes that the unobserved, true ability and the firm mover and occupation change dummy variables are uncorrelated, conditional on the mentioned proxy variables. With respect to the quality of the traineefirm and trainee-occupation matches, we control for the apprentices' statements on whether they want to stay with the training firm after training, whether they like to perform the typical tasks of their apprenticeship occupations, for their assessments of the perspectives in the occupation and of the quality of their supervisor, all measured during training at least one year before graduation.

If the proxies for ability and match qualities are good proxies that eliminate or greatly reduce ability bias, the remaining two sources of endogeneity will bias the OLS coefficients of mobility upwards and under-estimate the wage loss due to specific human capital. Hence, OLS provides a lower bound on the wage differentials. We treat the OLS coefficients as baseline results and address endogenous mobility by means of an endogenous treatment model (Heckman, 1978; Vella, 1998; Vella and Verbeek, 1999).

In our case, the endogenous regressor is multinomial instead of binary (on multiple treatments, see Lee, 1983; Dubin and McFadden, 1984; Dahl, 2002). It is a variable with three categories (i.e., two dummy variables) for firm stayers, firm movers, and occupation changers. The first equation of the model consists of a discrete choice model for mobility decisions, and the second equation is a wage regression.

$$
\begin{aligned}
y_{i j}^{*} & =\gamma_{j}^{0}+x_{i} \gamma_{j}^{x}+z_{i} \gamma_{j}^{z}+v_{i j} \quad j=s t, f m, o c \\
\ln w_{i} & =\beta^{0}+\beta^{f m} f m_{i}+\beta^{o c} o c_{i}+x_{i} \beta^{x}+l_{i} \lambda+u_{i}
\end{aligned}
$$

Equation (2) describes the choice of apprentices amongst three mobility alternatives based on the individual latent 'utilities' $y_{i j}^{*}$. The observed, optimal choice enters eq. (3) as dummy variables $\mathrm{fm}$ and $o c . x_{i}$ represents controls included in both equations, $z_{i}$ represents variables that influence the mobility decision but do not influence wages. $l_{i}$ represents the selection effect and will be derived from the choice equation, as explained below.

We use two different approaches to estimate eqs. (2) and (3). Both model the choice eq. (2) as a multinomial logit, and the log wage eq. (3) as a linear regression. Deb and Trivedi (2006) propose a simulated maximum likelihood method to estimate the joint distribution of endogenous treatment and outcome using a latent factor structure. Their model includes two lambda coefficients (for three choice categories) in the outcome equation that account for the selection effect.

15 Contrary to reading performance, PISA 2000 tested mathematics performance only for a subgroup of pupils. 
We compare the results of the Deb and Trivedi (DT) method with those of a standard two-step control function (CF) approach. We derive Mills ratios from a first-stage multinomial logit, applying a generalized version of the Dubin and McFadden (1984) approach. Bourguignon et al. (2007) showed that this version (DMF1 in their paper) performs well in Monte Carlo simulations of selection bias correction models and is their preferred option for small samples. The DMF1 approach involves one control function per choice alternative in the first stage, that is, $l_{i}$ includes three Mills ratios in wage regression (3). We assume that the treatment effect operates only through the intercept such that the coefficient vector $\beta^{x}$ is the same for all groups (as in DT). ${ }^{16}$ The two-step method has the advantage that it does not rely on simulation. However, two-step methods are inefficient and may result in inflated standard errors.

In both methods discussed in the previous sections, non-linear functional forms identify the parameters even if the set of variables in both equations is identical. For more robust identification, we include variables $\left(z_{i}\right)$ in the mobility eq. (2) that are excluded from wage regression (3). If these variables are correlated with mobility but uncorrelated with wages (after controlling for $x_{i}$ ), the model identifies the causal effect of mobility on wages.

Ideally, these variables reflect exogenous variation in the demand for apprenticeship graduates at firm and occupation level. In the absence of direct measures in the data, we use matched information from other data sources to create measures at the level of the local labour market (and industry) for average inter-firm and occupational mobility in the workforce and for employment growth within local industry. These measures for local labour market thickness or tightness will influence mobility behaviour at the individual level. We use three such variables, for which we assume no correlation with realized wages. The first variable is the average regional quit rate of apprentices in the relevant industry. We calculated regional, industry-specific quit rates from two Swiss surveys on costs and benefits of firms from apprenticeship training that contain information on the percentage of apprentices staying with their training firm after training. ${ }^{17}$ The second variable is the regional, occupation-specific share of workers up to age 25 who do not work in their learned occupation according to the Swiss population census of 2000. The third variable is due to Neal (1995), who used level of employment and employment growth in industries as variables affecting switching behaviour. As employment levels are not significantly related to mobility in our sample, we include only the employment growth variable. We expect that in industries with higher growth, apprentices are more likely to receive a job offer by their training firm and are more likely to stay. Vice versa, they are forced to leave the firm in the case of a non-growing industry, because the firm might not want to grow by hiring the former apprentice as a skilled worker. ${ }^{18}$ We calculated employment growth from the firm census data. We matched all regional variables to the apprentices based on their place of

16 Due to the limited sample size, we are not able to allow for differences in the $\beta^{X}$ coefficients across mobility groups as would be possible in a full switching regression.

17 We thank Samuel Muehlemann and Stefan Wolter for the permission to use the cost-benefit data from 2000 and 2004 (see Schweri et al., 2003; Muehlemann et al., 2007). We use the pooled data set containing 4,729 training firms. To account for possible outliers in quit rates, we use a dummy indicating a quit rate above the sample average.

18 Some authors use information on firm closures or sharp declines in firm size to analyse the effects of mobility (Fitzenberger and Spitz, 2004; Dustmann and Meghir, 2005). We do not find a significant effect of firm size reductions on mobility, and there are no suitable data available on the former. 
residence and occupation/industry during apprenticeship training. The relevant individual regions encompass all municipalities reachable within 30 minutes by car from the apprentice's residential municipality. We have thus created a specific region for every community in the data (see Online Appendix Table A2 for more details). ${ }^{19}$

\section{Results}

\subsection{Main findings}

Table 1 describes the mobility behaviour of employed apprenticeship graduates. Roughly one half of the graduates continue to work in their training firms, $42 \%$ change firms but not occupation, and $7 \%$ change firm and move out of the two-digit occupation in which they were trained. The proportion of occupation changes is rather low one year after completing apprenticeship training. If we use the five-digit definition, we find 4.5 percentage points more occupation changes than with the two-digit definition. First insights on the transferability of the human capital can be gained by using apprentices' own assessments of the usefulness of what they learned in training (in firms as well as in school) to their current work. Dustmann and Schoenberg (2007) use such a categorical variable and report results for the degree of specificity of what is learned in training in Germany (firm-specific: $4.5 \%$, occupation-specific: $34.3 \%$ ). Replicating their calculations, the last column of Table 2 shows that firm movers report values that are only $2.4 \%$ below the values reported by firm stayers ('firm-specific component'), whereas occupation changers report values that are $34.4 \%$ below the average value of firm movers within the learned occupation ('occupationspecific component'). Our results are virtually identical to those obtained by Dustmann and Schoenberg (2007) and indicate a substantial occupation-specific component and a negligible firm-specific component.

The wage distributions in Fig. 1 show that average wages are highest for stayers, followed by firm movers and occupation changers. Stayers earn 23.31 CHF per hour, firm movers earn 22.86 CHF, and occupation changers earn 21.74 CHF (see Online Appendix Table A2). The wage distributions are broader for movers than for stayers and even broader for occupation changers. This is also the pattern that we would expect for the unobservable wage offer distribution, because the offers come from very different firms in the case of occupation changers.

Table 1. Mobility patterns after training (status one year after graduation)

\begin{tabular}{lcccc}
\hline & \multicolumn{2}{c}{ Definition of occupational change in occup. code digits (\%) } \\
\cline { 2 - 5 } Category & 5-digit & 3-digit & 2-digit & 1-digit \\
\hline Job in training firm (Stayer) & 51.03 & 51.03 & 51.03 & 51.03 \\
$\begin{array}{l}\text { Firm change within occupation } \\
\quad \text { Firm mover })\end{array}$ & 37.24 & 41.23 & 41.80 & 42.60 \\
$\begin{array}{l}\text { Firm change across occupation } \\
\text { (Occupational change) }\end{array}$ & 11.73 & 7.74 & 7.18 & 6.38 \\
\hline \begin{tabular}{l} 
Total \\
\hline
\end{tabular} & 100.00 & 100.00 & 100.00 & 100.00 \\
\hline
\end{tabular}

19 Switzerland is composed of about 2,700 communities. Apprentices in the sample lived in 390 different communities. 
Table 2. Usefulness of the skills acquired in training for current job

\begin{tabular}{|c|c|c|c|c|c|c|}
\hline & \multicolumn{2}{|c|}{ Skills training firm } & \multicolumn{2}{|c|}{ Skills voc. school } & \multicolumn{2}{|c|}{ Mean of both sources } \\
\hline & Mean & SD & Mean & SD & Mean & SD \\
\hline Firm stayer & 3.60 & $(0.62)$ & 3.02 & $(0.78)$ & 3.31 & $(0.58)$ \\
\hline Firm mover (same occupation) & 3.35 & $(0.76)$ & 3.11 & $(0.81)$ & 3.23 & $(0.64)$ \\
\hline Occupational changer & 2.12 & $(0.95)$ & 2.12 & $(0.94)$ & 2.12 & $(0.84)$ \\
\hline
\end{tabular}

Note: Respondents rated the usefulness of the skills for the current job on a scale ranging from 1, 'not useful', to 4 , 'very useful'.

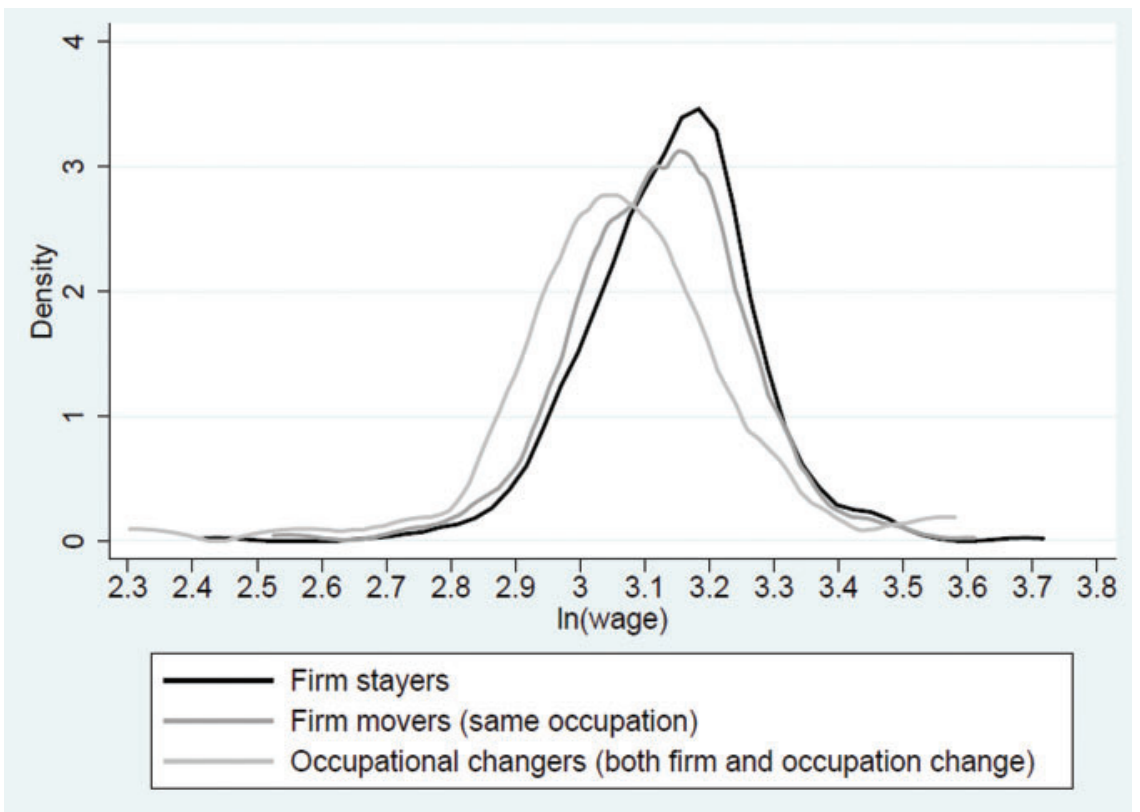

Fig. 1 Distribution of the logarithm of hourly wages by mobility status one year after graduation

The first OLS wage regression in Table 3 (second column) does not yet include ability or match quality proxies. The results show no significant difference in wages between stayers and firm movers, but wages for occupation changers are lower by $5.2 \%$ compared with stayers, and the difference is statistically significant.

We add ability and match quality proxy variables in the OLS wage regression in the third column. The coefficients of the mobility dummies remain very similar, with occupation changers earning $4.5 \%$ less than firm stayers. Looking at the new covariates, we see that the PISA literacy test score at age 15 is significant: an increase by 1 standard deviation on the international PISA scale, that is, 100 score points, increases wages by $1.4 \%$. We do not find a significant interaction effect between mobility and test score (results not shown). Individuals with higher mathematical self-concept, higher self-efficacy in work tasks, and higher extrinsic motivation also earn significantly more, which shows that these ability and 
Table 3. Wage estimations: OLS, Deb-Trivedi (DT), and control function (CF) estimates; first stage mlogit

\begin{tabular}{|c|c|c|c|c|c|c|c|}
\hline & \multirow[t]{2}{*}{$\begin{array}{l}\text { Ln(wage) } \\
\text { OLS I }\end{array}$} & \multirow[t]{2}{*}{$\begin{array}{l}\text { Ln(wage) } \\
\text { OLS II }\end{array}$} & \multirow[t]{2}{*}{$\begin{array}{l}\text { Ln(wage) } \\
\text { DT model }\end{array}$} & \multirow[t]{2}{*}{$\begin{array}{l}\text { Ln(wage) } \\
\text { CF estim. }\end{array}$} & \multicolumn{3}{|c|}{$\begin{array}{c}\text { MLOGIT Average } \\
\text { marginal effects }\end{array}$} \\
\hline & & & & & $\begin{array}{l}\text { Firm } \\
\text { mover }\end{array}$ & $\begin{array}{l}\text { Occ. } \\
\text { change }\end{array}$ & $\begin{array}{l}\text { Firm } \\
\text { stayer }\end{array}$ \\
\hline Firm mover & $\begin{array}{r}-0.001 \\
(0.010)\end{array}$ & $\begin{array}{c}0.001 \\
(0.011)\end{array}$ & $\begin{array}{c}0.001 \\
(0.021)\end{array}$ & $\begin{array}{c}0.022 \\
(0.036)\end{array}$ & & & \\
\hline Occupational change & $\begin{array}{l}e-0.052 * * * \\
(0.018)\end{array}$ & $\begin{array}{c}-0.045 * \\
(0.018)\end{array}$ & $\begin{array}{c}-0.094 * * * \\
(0.022)\end{array}$ & $\begin{array}{c}* 0.130 * * \\
(0.059)\end{array}$ & & & \\
\hline $\begin{array}{l}\text { PISA test score } \\
\text { reading literacy }\end{array}$ & & $\begin{array}{l}0.014 * * \\
(0.006)\end{array}$ & $\begin{array}{l}0.013 * * \\
(0.006)\end{array}$ & $\begin{array}{c}0.012 \\
(0.008)\end{array}$ & $\begin{array}{c}0.017 \\
(0.021)\end{array}$ & $\begin{array}{c}-0.028 * * \\
(0.012)\end{array}$ & $\begin{array}{c}0.011 \\
(0.020)\end{array}$ \\
\hline $\begin{array}{l}\text { Mathematics self- } \\
\text { concept }\end{array}$ & & $\begin{array}{l}0.011 * * \\
(0.005)\end{array}$ & $\begin{array}{l}0.011^{* *} \\
(0.005)\end{array}$ & $\begin{array}{l}0.012 * * \\
(0.006)\end{array}$ & $\begin{array}{c}0.002 \\
(0.018)\end{array}$ & $\begin{array}{c}0.011 \\
(0.011)\end{array}$ & $\begin{array}{r}-0.012 \\
(0.017)\end{array}$ \\
\hline $\begin{array}{l}\text { High GPA in } \\
\text { apprent. training }\end{array}$ & & $\begin{array}{c}0.006 \\
(0.011)\end{array}$ & $\begin{array}{c}0.005 \\
(0.011)\end{array}$ & $\begin{array}{c}0.003 \\
(0.011)\end{array}$ & $\begin{array}{c}0.049 \\
(0.037)\end{array}$ & $\begin{array}{r}-0.014 \\
(0.024)\end{array}$ & $\begin{array}{r}-0.036 \\
(0.035)\end{array}$ \\
\hline $\begin{array}{l}\text { Self-efficacy in } \\
\text { work tasks }\end{array}$ & & $\begin{array}{l}0.025^{* *} \\
(0.010)\end{array}$ & $\begin{array}{l}0.026 * * * \\
(0.010)\end{array}$ & $\begin{array}{l}0.026 * * \\
(0.011)\end{array}$ & $\begin{array}{r}-0.022 \\
(0.034)\end{array}$ & $\begin{array}{c}0.026 \\
(0.020)\end{array}$ & $\begin{array}{r}-0.004 \\
(0.032)\end{array}$ \\
\hline Extrinsic motivation & & $\begin{array}{l}0.019 * * \\
(0.010)\end{array}$ & $\begin{array}{l}0.018 * * \\
(0.009)\end{array}$ & $\begin{array}{c}0.018 \\
(0.012)\end{array}$ & $\begin{array}{r}-0.026 \\
(0.032)\end{array}$ & $\begin{array}{r}-0.034 * \\
(0.018)\end{array}$ & $\begin{array}{c}0.060 * \\
(0.031)\end{array}$ \\
\hline $\begin{array}{l}\text { Vocational } \\
\text { baccalaureate }\end{array}$ & & $\begin{array}{r}-0.018 \\
(0.011)\end{array}$ & $\begin{array}{r}-0.018 \\
(0.011)\end{array}$ & $\begin{array}{r}-0.017 \\
(0.012)\end{array}$ & $\begin{array}{r}-0.064 * \\
(0.038)\end{array}$ & $\begin{array}{r}-0.023 \\
(0.025)\end{array}$ & $\begin{array}{l}0.087 * * \\
(0.036)\end{array}$ \\
\hline $\begin{array}{l}\text { High track in lower- } \\
\text { secondary school }\end{array}$ & & $\begin{array}{c}0.015 \\
(0.011)\end{array}$ & $\begin{array}{c}0.017 \\
(0.011)\end{array}$ & $\begin{array}{c}0.018 \\
(0.011)\end{array}$ & $\begin{array}{c}-0.082 * * \\
(0.037)\end{array}$ & $\begin{array}{l}0.050 * * \\
(0.022)\end{array}$ & $\begin{array}{c}0.032 \\
(0.036)\end{array}$ \\
\hline $\begin{array}{l}\text { Likes tasks of } \\
\text { training occupation }\end{array}$ & & $\begin{array}{r}-0.006 \\
(0.008)\end{array}$ & $\begin{array}{r}-0.007 \\
(0.008)\end{array}$ & $\begin{array}{r}-0.010 \\
(0.008)\end{array}$ & $\begin{array}{c}0.027 \\
(0.026)\end{array}$ & $\begin{array}{r}-0.017 \\
(0.014)\end{array}$ & $\begin{array}{r}-0.010 \\
(0.025)\end{array}$ \\
\hline $\begin{array}{l}\text { Wants to work } \\
\text { in training firm }\end{array}$ & & $\begin{array}{c}0.005 \\
(0.010)\end{array}$ & $\begin{array}{c}0.005 \\
(0.011)\end{array}$ & $\begin{array}{c}0.011 \\
(0.013)\end{array}$ & $\begin{array}{l}-0.204 * * \\
(0.030)\end{array}$ & $\begin{array}{c}0.006 \\
(0.018)\end{array}$ & $\begin{array}{l}0.198 * * * \\
(0.029)\end{array}$ \\
\hline $\begin{array}{l}\text { in training firm } \\
\text { Perspectives }\end{array}$ & & $\begin{array}{c}(0.010) \\
0.001\end{array}$ & $\begin{array}{l}(0.011) \\
-0.001\end{array}$ & $\begin{array}{c}(0.013) \\
-0.002\end{array}$ & $\begin{array}{l}(0.030) \\
0.024\end{array}$ & $-0.032 * * *$ & 0.008 \\
\hline in occupation & & $(0.006)$ & $(0.006)$ & $(0.006)$ & $(0.020)$ & $(0.012)$ & $(0.019)$ \\
\hline $\begin{array}{l}\text { Perceived quality } \\
\text { of supervisor }\end{array}$ & & $\begin{array}{c}0.010 \\
(0.009)\end{array}$ & $\begin{array}{c}0.008 \\
(0.009)\end{array}$ & $\begin{array}{c}0.006 \\
(0.009)\end{array}$ & $\begin{array}{c}0.000 \\
(0.030)\end{array}$ & $\begin{array}{l}-0.049 * * * \\
(0.017)\end{array}$ & $\begin{array}{c}0.048 * \\
(0.028)\end{array}$ \\
\hline Female & $\begin{array}{l}-0.041 * * \\
(0.011)\end{array}$ & $\begin{array}{c}-0.033 * * * \\
(0.012)\end{array}$ & $\begin{array}{c}* 0.033 * * * \\
(0.011)\end{array}$ & $\begin{array}{c}* 0.035 * * * \\
(0.012)\end{array}$ & $\begin{array}{c}0.007 \\
(0.040)\end{array}$ & $\begin{array}{r}-0.006 \\
(0.023)\end{array}$ & $\begin{array}{r}-0.001 \\
(0.038)\end{array}$ \\
\hline $\begin{array}{l}\text { Immigrant: second- } \\
\text { generation }\end{array}$ & $\begin{array}{c}0.025 \\
(0.018)\end{array}$ & $\begin{array}{c}0.027 \\
(0.018)\end{array}$ & $\begin{array}{c}0.026 \\
(0.017)\end{array}$ & $\begin{array}{c}0.025 \\
(0.023)\end{array}$ & $\begin{array}{c}0.049 \\
(0.060)\end{array}$ & $\begin{array}{r}-0.019 \\
(0.033)\end{array}$ & $\begin{array}{r}-0.029 \\
(0.058)\end{array}$ \\
\hline $\begin{array}{l}\text { Immigrant: first- } \\
\text { generation }\end{array}$ & $\begin{array}{r}-0.006 \\
(0.016)\end{array}$ & $\begin{array}{r}-0.008 \\
(0.016)\end{array}$ & $\begin{array}{r}-0.010 \\
(0.016)\end{array}$ & $\begin{array}{r}-0.009 \\
(0.019)\end{array}$ & $\begin{array}{r}-0.075 \\
(0.057)\end{array}$ & $\begin{array}{r}-0.019 \\
(0.033)\end{array}$ & $\begin{array}{l}0.093 * \\
(0.054)\end{array}$ \\
\hline $\begin{array}{l}\text { French-speaking } \\
\text { part of Switzerland }\end{array}$ & $\begin{array}{c}0.018 \\
(0.012)\end{array}$ & $\begin{array}{l}0.029 \% \\
(0.017)\end{array}$ & $\begin{array}{l}0.029 * \\
(0.016)\end{array}$ & $\begin{array}{c}0.026 \\
(0.019)\end{array}$ & $\begin{array}{r}-0.042 \\
(0.059)\end{array}$ & $\begin{array}{c}0.028 \\
(0.035)\end{array}$ & $\begin{array}{c}0.014 \\
(0.056)\end{array}$ \\
\hline $\begin{array}{l}\text { Italian-speaking } \\
\text { part of Switzerland }\end{array}$ & $\begin{array}{l}-0.099 * * * \\
(0.020)\end{array}$ & $\begin{array}{c}-0.084 * * * \\
(0.020)\end{array}$ & $\begin{array}{c}*-0.080 * * * \\
(0.020)\end{array}$ & $\begin{array}{c}* 0.078 * * * \\
(0.024)\end{array}$ & $\begin{array}{r}-0.081 \\
(0.070)\end{array}$ & $\begin{array}{l}0.089 * * \\
(0.038)\end{array}$ & $\begin{array}{r}-0.008 \\
(0.068)\end{array}$ \\
\hline $\begin{array}{l}\text { Parental educ.: } \\
\text { upper-secondary }\end{array}$ & $\begin{array}{r}-0.003 \\
(0.010)\end{array}$ & $\begin{array}{r}-0.005 \\
(0.010)\end{array}$ & $\begin{array}{r}-0.004 \\
(0.010)\end{array}$ & $\begin{array}{r}-0.004 \\
(0.011)\end{array}$ & $\begin{array}{r}-0.015 \\
(0.035)\end{array}$ & $\begin{array}{c}0.015 \\
(0.020)\end{array}$ & $\begin{array}{r}-0.000 \\
(0.033)\end{array}$ \\
\hline $\begin{array}{l}\text { Parental educ.: } \\
\text { tertiary }\end{array}$ & $\begin{array}{r}-0.003 \\
(0.011)\end{array}$ & $\begin{array}{r}-0.005 \\
(0.011)\end{array}$ & $\begin{array}{r}-0.008 \\
(0.011)\end{array}$ & $\begin{array}{r}-0.011 \\
(0.012)\end{array}$ & $\begin{array}{c}0.035 \\
(0.040)\end{array}$ & $\begin{array}{l}-0.055 * \\
(0.026)\end{array}$ & $\begin{array}{c}0.019 \\
(0.038)\end{array}$ \\
\hline $\begin{array}{l}\text { Size of training firm: } \\
11-100\end{array}$ & $\begin{array}{c}0.012 \\
(0.010)\end{array}$ & $\begin{array}{c}0.010 \\
(0.010)\end{array}$ & $\begin{array}{c}0.011 \\
(0.010)\end{array}$ & $\begin{array}{c}0.012 \\
(0.011)\end{array}$ & $\begin{array}{c}-0.079 * \\
(0.033)\end{array}$ & $\begin{array}{c}0.007 \\
(0.019)\end{array}$ & $\begin{array}{l}0.072 * * \\
(0.032)\end{array}$ \\
\hline Size of training firm: & 0.014 & 0.013 & 0.014 & 0.016 & $-0.086^{*}$ & 0.008 & $0.078 *$ \\
\hline
\end{tabular}


Table 3. (continued)

\begin{tabular}{|c|c|c|c|c|c|c|c|}
\hline & \multirow[t]{2}{*}{$\begin{array}{l}\text { Ln(wage) } \\
\text { OLS I }\end{array}$} & \multirow[t]{2}{*}{$\begin{array}{l}\text { Ln(wage) } \\
\text { OLS II }\end{array}$} & \multirow[t]{2}{*}{$\begin{array}{l}\text { Ln(wage) } \\
\text { DT model }\end{array}$} & \multirow[t]{2}{*}{$\begin{array}{l}\text { Ln(wage) } \\
\text { CF estim. }\end{array}$} & \multicolumn{3}{|c|}{$\begin{array}{l}\text { MLOGIT Average } \\
\text { marginal effects }\end{array}$} \\
\hline & & & & & $\begin{array}{l}\text { Firm } \\
\text { mover }\end{array}$ & $\begin{array}{l}\text { Occ. } \\
\text { change }\end{array}$ & $\begin{array}{l}\text { Firm } \\
\text { stayer }\end{array}$ \\
\hline $100+$ & $(0.014)$ & $(0.014)$ & $(0.014)$ & $(0.014)$ & $(0.049)$ & $(0.028)$ & $(0.047)$ \\
\hline $\begin{array}{l}\text { Size of current firm: } \\
11-100\end{array}$ & $\begin{array}{l}0.018 * \\
(0.010)\end{array}$ & $\begin{array}{l}0.020 * \\
(0.010)\end{array}$ & $\begin{array}{l}0.021 * * \\
(0.010)\end{array}$ & $\begin{array}{l}0.021 * * \\
(0.011)\end{array}$ & $\begin{array}{r}-0.050 \\
(0.034)\end{array}$ & $\begin{array}{c}0.013 \\
(0.021)\end{array}$ & $\begin{array}{c}0.037 \\
(0.033)\end{array}$ \\
\hline $\begin{array}{l}\text { Size of current } \\
\text { firm: } 100+\end{array}$ & $\begin{array}{l}0.058 * * * \\
(0.014)\end{array}$ & $\begin{array}{l}0.061 * * * \\
(0.014)\end{array}$ & $\begin{array}{l}0.063 * * * \\
(0.014)\end{array}$ & $\begin{array}{l}0.065 * * * \\
(0.016)\end{array}$ & $\begin{array}{l}-0.137 * * * \\
(0.047)\end{array}$ & $\begin{array}{c}0.023 \\
(0.026)\end{array}$ & $\begin{array}{l}0.114 * * \\
(0.045)\end{array}$ \\
\hline Unemployment rate & $\begin{array}{r}-0.006 \\
(0.005)\end{array}$ & $\begin{array}{r}-0.008 * \\
(0.005)\end{array}$ & $\begin{array}{r}-0.007 \\
(0.004)\end{array}$ & $\begin{array}{r}-0.007 \\
(0.006)\end{array}$ & $\begin{array}{r}-0.004 \\
(0.015)\end{array}$ & $\begin{array}{c}0.008 \\
(0.008)\end{array}$ & $\begin{array}{r}-0.004 \\
(0.015)\end{array}$ \\
\hline $\begin{array}{l}\text { Month between } \\
\text { training and job }\end{array}$ & $\begin{array}{c}0.002 \\
(0.003)\end{array}$ & $\begin{array}{c}0.003 \\
(0.003)\end{array}$ & $\begin{array}{c}0.003 \\
(0.003)\end{array}$ & $\begin{array}{c}0.004 \\
(0.003)\end{array}$ & $\begin{array}{c}0.007 \\
(0.010)\end{array}$ & $\begin{array}{c}0.006 \\
(0.005)\end{array}$ & $\begin{array}{r}-0.013 \\
(0.010)\end{array}$ \\
\hline $\begin{array}{l}\text { Tenure in month } \\
\text { at the current job }\end{array}$ & $\begin{array}{c}0.002 \\
(0.001)\end{array}$ & $\begin{array}{l}0.002 * \\
(0.001)\end{array}$ & $\begin{array}{c}0.002 \\
(0.001)\end{array}$ & $\begin{array}{c}0.003 \\
(0.002)\end{array}$ & $\begin{array}{r}-0.008 \\
(0.005)\end{array}$ & $\begin{array}{r}-0.000 \\
(0.003)\end{array}$ & $\begin{array}{l}0.009 * \\
(0.005)\end{array}$ \\
\hline \multicolumn{8}{|l|}{ Training occupation } \\
\hline $\begin{array}{l}\& \text { duration } \\
\qquad \text { (11 dummies) }\end{array}$ & Yes & Yes & Yes & Yes & Yes & Yes & Yes \\
\hline $\begin{array}{l}\text { Spells before current } \\
\text { job (6 dummies) }\end{array}$ & Yes & Yes & Yes & Yes & Yes & Yes & Yes \\
\hline \multirow{2}{*}{$\begin{array}{l}\text { High regional } \\
\text { quit rate }\end{array}$} & & & & & \multicolumn{2}{|c|}{$0.124 * * *-0.017$} & $-0.107 * * *$ \\
\hline & & & & & $(0.031)$ & $(0.019)$ & $(0.030)$ \\
\hline Regional rate of & & & & & 0.225 & $0.298 *$ & -0.523 \\
\hline occupation change & & & & & $(0.349)$ & $(0.180)$ & $(0.342)$ \\
\hline Regional & & & & & -0.272 & -0.188 & $0.461 * *$ \\
\hline employment growth & & & & & $(0.210)$ & $(0.137)$ & $(0.198)$ \\
\hline Lambda/Mills & & & -0.002 & -0.004 & & & \\
\hline firm mover & & & $(0.023)$ & $(0.017)$ & & & \\
\hline Lambda/Mills & & & $0.062 * * *$ & $0.047^{* *}$ & & & \\
\hline occ. change & & & $(0.016)$ & $(0.020)$ & & & \\
\hline \multirow[t]{2}{*}{ Mills firm stayer } & & & & 0.011 & & & \\
\hline & & & & $(0.013)$ & & & \\
\hline \multirow[t]{2}{*}{ Constant } & $3.163 * * *$ & $2.986 * * *$ & $3.001 * * *$ & $3.006^{* * * *}$ & & & \\
\hline & $(0.025)$ & $(0.056)$ & $(0.055)$ & $(0.073)$ & & & \\
\hline$N$ & 878 & 878 & 878 & 878 & & 878 & \\
\hline$R$-sq / pseudo $R$-sq & 0.282 & 0.311 & & 0.318 & & 0.334 & \\
\hline
\end{tabular}

Notes: ${ }^{*} p<0.10, * * p<0.05, * * * p<0.01$. CF estimates: bootstrapped standard errors (2,000 rep.) in parentheses. Reference group: firm mover, Swiss, German-speaking part, lower track in lower-secondary school, parental education: comp. school, firm sizes: 1-10 full-time-equivalents. Results for training occupation and spells dummies and for DT mmlogit coefficients in Table A3 (online appendix)

personality variables measured during training or before are relevant for later labour market outcomes.

The multinomial logit results in the last three columns of Table 3 allow us to assess the selection process into firm and occupational mobility. We present average marginal effects. 
Many ability variables have no significant influence on mobility; yet as the PISA reading test score increases by 1 standard deviation, the probability of occupation change reduces by 2.8 percentage points. Trainees that earn a vocational baccalaureate during their apprenticeship period are more likely to stay with their training firm. Most matching variables show highly significant and substantial effects: a positive assessment of the career prospects in the learned occupation and a high perceived quality of training both reduce the probability of changing occupation. Wanting to stay in the training firm strongly increases the probability of working in the training firm one year after training.

Overall, we find only limited evidence for adverse selection on ability in post-training mobility. A possible explanation is that positive and adverse selection exist at the same time, such that the mean effect of ability on mobility is rather small. Occupation changers have a somewhat lower PISA score and are less likely to earn a vocational baccalaureate, but the experience during training as represented by the match quality variables is more influential for mobility decisions than ability. The match quality variables, however, do not significantly influence wages in the OLS regression. Accordingly, ability and match quality variables are important to understand mobility decisions and wage setting, but exert little influence on the wage differentials between stayers, firm movers, and occupation changers.

If our ability and match quality variables are good proxies, the remaining bias in OLS (from heterogeneous effects and endogenously chosen mobility) should be an upwards bias. Thus, the OLS coefficient of $4.5 \%$ wage loss for occupation changers provides a lower bound (in absolute terms) for the short-term wage loss due to occupation-specific human capital acquired during apprenticeship training.

The last columns of Table 3 show mlogit results for the mobility equation that acts as first stage for the endogenous treatment models. The three variables excluded from the (second stage) wage equation are jointly significant $(p<0.0001)$ in a Wald test. The regional quit rate and regional employment growth affect individuals' probability to stay in the firm significantly; the regional rate of occupation change increases individuals' probability to change occupation. ${ }^{20}$

The Deb and Trivedi (2006) endogenous treatment model accounts for the endogeneity of job and occupation changes. For most covariates, the DT results in the fourth column of Table 3 are very similar to the OLS results. Yet the wage loss of an occupation changer relative to a stayer increases from $4.5 \%$ to $9.4 \%$. This result is in line with our prediction that-controlled for ability and match quality-OLS under-estimates the wage loss due to switches out of the learned occupation. The lambda coefficient for occupation change is significantly positive, indicating that selection into mobility is not random, conditional on the observed $x$-variables.

The point estimate for firm movers is almost equal to 0 and insignificant. Two interpretations are possible: either there is no substantial firm-specific skills component on average, or the training firm acquires all the returns on firm-specific training investments. Irrespective of the interpretation, there is no evidence that firms distort training contents towards firm-specific skills in an effort to retain workers. Of course, training firms might offer contracts with modest post-training wages and back-loaded compensation that reward tenure as a strategy

20 Concerning the variable 'regional rate of occupation change', its marginal effect is significant at the $10 \%$ level for occupation change against the two other alternatives (see Table 3); however, its coefficient in the first stage DT mixed mlogit is significant at the $5 \%$ level between the alternatives staying and changing occupation (Table $\mathrm{A} 3$ in the online appendix). 
to retain apprentices (Stevens, 2004). Firm-specific human capital would thus matter for lifetime earnings. We would need data on apprentices with many years of post-training labour market experience to analyse such behaviour by training firms.

\subsection{Robustness checks}

First, we compare the results of the Deb and Trivedi approach with the two-step control function approach described in the section on the estimation setup. The fifth column in Table $3(\mathrm{CF})$ shows that occupation change is again associated with a higher wage loss than in the OLS models, whereas firm stayers and movers show no significant wage difference. The point estimate of occupation change is larger than estimated by the DT method, however, the qualitative results remain the same. The two-step procedure comes at the cost of markedly higher (bootstrapped) standard errors leading to an imprecise estimation of the mobility effects.

Second, we redefine the occupation change dummy variable using five-digit, three-digit, and one-digit definitions in place of the two-digit definition of an occupation that we deem most adequate (see data section). These different definitions of occupation change imply different delimitations between firm- and occupation-specific human capital in our setting (see Table 1). Wage losses are smallest (6.3\% in DT estimation, see Table 4) when occupational changes mean small (five-digit) changes, which is what we would expect from human capital theory.

Third, we change the calculation of the regional variables excluded from the wage equation ( $z$-variables). If we define a 45 -minute travel time radius from the apprentices' places of residence instead of 30 minutes, the results ${ }^{21}$ are very similar to those in Table 3 . The occupation change dummy coefficient is virtually identical with -0.093 .

Table 4. Overview of key results obtained by varying the definition of occupational change

\begin{tabular}{lcccc}
\hline & 5-digit & 3-digit & 2-digit & 1-digit \\
\hline Results of OLS wage regression & & & & \\
Firm mover & -0.001 & -0.000 & 0.001 & -0.000 \\
& $(0.011)$ & $(0.011)$ & $(0.011)$ & $(0.010)$ \\
Occupational change & -0.018 & $-0.038 * *$ & $-0.045 * *$ & $-0.044 * *$ \\
& $(0.015)$ & $(0.018)$ & $(0.018)$ & $(0.019)$ \\
Results of Deb-Trivedi treatment regression & & & & \\
Firm mover & -0.006 & -0.001 & 0.001 & -0.000 \\
& $(0.021)$ & $(0.021)$ & $(0.021)$ & $(0.020)$ \\
Occupational change & $-0.063 * * *$ & $-0.083 * * *$ & $-0.094 * * *$ & $-0.093 * * *$ \\
& $(0.023)$ & $(0.023)$ & $(0.022)$ & $(0.022)$ \\
Lambda firm mover & 0.004 & 0.000 & -0.002 & -0.001 \\
& $(0.023)$ & $(0.023)$ & $(0.023)$ & $(0.023)$ \\
Lambda occ. change & $0.056 * *$ & $0.058 * *$ & $0.062 * * *$ & $0.062 * * *$ \\
& $(0.023)$ & $(0.019)$ & $(0.016)$ & $(0.016)$ \\
\hline
\end{tabular}

Notes: ${ }^{*} p<0.10, * * p<0.05, * * p<0.01$. OLS results: same covariates as in third column in Table 3 . The two-digit definition is the one used throughout the article. The four-digit level coincides with the three-digit level nearly everywhere throughout the nomenclature.

21 These and the following results in the text are not shown due to space restrictions, but are available from the authors. 
Fourth, we estimate the DT model using only two, one, or none of the $z$-variables in the mobility equation, thus relying on non-linear functional form for identification. The results are very similar; in particular the occupation change dummy remains significant and between $-9.0 \%$ and $-9.5 \%$.

Finally, if we include the last training wage as an additional control for unobserved heterogeneity in training (Euwals and Winkelmann, 2004), it is weakly significant in the DT wage regression with positive sign. The wage effects of mobility remain virtually the same.

\section{Conclusions}

Firm-based apprenticeships have been suspected of transferring an overly specific, narrow set of skills. The literature available on human capital transferability for Germany comes to heterogeneous results and is probably not generalizable to other countries; however, several studies have reported high transferability of skills learned in apprenticeship.

We show that in Switzerland, with its lightly regulated labour market, firm mobility within one year after completing an apprenticeship is high $49 \%$ of all apprenticeship graduates, including occupation changers), whereas occupational mobility is limited $(7 \%$ of all graduates). In OLS wage regressions, we find no significant differences in wages of firm stayers and firm movers within their learned occupation defined at the two-digit occupation level, even when we control for ability and match quality proxies. Firm movers with occupation change, however, earn almost 5\% less. Applying a treatment regression approach to account for endogenous mobility decisions, we still find no wage effect for firm movers who stay within the occupation, but a negative wage differential of approximately $9 \%$ for occupation changers.

We conclude that within the occupational field of an apprenticeship, the human capital acquired is widely transferable to other firms after graduation. Transferability is more limited for changes beyond the occupational field: apprenticeship graduates that undertake such changes earn lower wages, with the magnitude of the wage cut depending on the distance between occupations. Adverse selection and the match quality with the training firm and the training occupation hardly affect these findings: whilst the match quality matters for mobility decisions in our estimations, it does not affect post-mobility wages. Conversely, we find that several ability variables have an effect on wages (in the usual direction); however, for the mobility decision, only PISA test scores show some adverse selection into occupation change.

Whilst firm-specific human capital does not seem to play a significant role for Swiss apprentices' early labour market wages, on average, occupation-specific human capital is an important component of apprenticeship training and accounts for a portion of the return to training.

Overall, Swiss apprenticeship curricula and quality assurances as defined by legal regulations seem to be successful in producing transferable skills and knowledge such that apprenticeships are not restricted to a very narrow set of skills. There is no evidence that training firms distort the regulated training content towards firm-specific components in an effort to reduce across-firm mobility of workers. High across-firm transferability of acquired skills is also in line with the findings of cost-benefit studies for Switzerland, which show that Swiss apprentices bear the full costs of training on average. Still, the provision of widely transferable human capital should be stressed in ongoing curricula reforms. Our findings on the importance of occupation-specific human capital highlight the need for 
continuing vocational training to continuously update or retrain skilled workers according to changing labour market needs. Otherwise, apprenticeships might reduce long-term flexibility compared to a general education system that does not require a choice of an occupation at the age of 16 . At the same time, we may also interpret the importance of occupation-specific human capital as necessary condition for gains that accrue from specialization, both at the individual level and for the economy as a whole. Relatively high rates of (lifetime) returns to apprenticeships (Weber et al., 2001), compared with individuals who do not follow any post-compulsory education, support the view that the apprenticeship system is successful in supplying young adults with the skills demanded by Swiss firms. More empirical studies are required to analyse the relative long-term costs and benefits of education systems that rely on vocational education with early specialization.

\section{Supplementary material}

Supplementary material is available online at the OUP website.

\section{Acknowledgements}

This article draws on discussions and work with Annina Eymann, Ilaria Finzi, Marc Fuhrer and Fulvio Mulatero. We thank Stefan Boes, Michael Gerfin, Andreas Kuhn, Cain Polidano, Stefan Wolter, three anonymous referees, and participants at the EALE and ESPE congresses and the VET congress for helpful comments. Part of the work was done whilst Jürg Schweri was visitor at the Centre for Research in Economics of Education at the University of Bern.

\section{Funding}

Federal Office for Professional Education and Technology (OPET) through its Leading House on the Economics of Education, Firm Behaviour and Training Policies.

\section{References}

Acemoglu, D. and Pischke, J.-S. (1998) Why do firms train? Theory and evidence, Quarterly Journal of Economics, 113, 79-119.

Acemoglu, D. and Pischke, J.-S. (2000) Certification of training and training outcomes, European Economic Review, 44, 917-27.

Bassanini, A., Booth, A., Brunello, G., De Paola, M., and Leuven, E. (2007) Workplace training in Europe, in G., Brunello, P., Garibaldi, and E., Wasmer (eds) Education and Training in Europe, Oxford University Press, Oxford.

Becker, G.S. (1962) Investment in human capital: a theoretical analysis, Journal of Political Economy, 70, 9-49.

Bertschy, K., Cattaneo, M., and Wolter, S. (2009) PISA and the transition into the labour market, Labour, 11, 111-37.

Bougheas, S. and Georgellis, Y. (2004) Early career mobility and earnings profiles of German apprentices: theory and empirical evidence, Labour, 18, 233-63.

Bourguignon, F., Fournier, M., and Gurgand, M. (2007) Selection bias corrections based on the multinomial logit model: Monte Carlo comparisons, Journal of Economic Surveys, 21, 174-205.

Brunner, B. and Kuhn, A. (2014) The impact of labor market entry conditions on initial job assignment and wages. Journal of Population Economics, 27, 705-38. 
CCRE. (2014) Swiss Education Report 2014, Swiss Coordination Centre for Research in Education, Aarau.

Clark, D. and Fahr, R. (2002) The promise of workplace training for non-college bound youth: theory and evidence from German apprenticeship, CEP Discussion Papers dp0518, Centre for Economic Performance, LSE.

Dahl, G. (2002) Mobility and the returns to education: testing a Roy Model with multiple markets, Econometrica, 70, 2367-420.

Deb, P. and Trivedi, P. (2006) Specification and simulated likelihood estimation of a non-normal treatment-outcome model with selection: application to health care utilization, Econometrics Journal, 9, 307-31.

Dubin, J. and McFadden, D. (1984) An econometric analysis of residential electric appliance holdings and Consumption, Econometrica, 52, 345-62.

Dustmann, C. and Schoenberg, U. (2007) Apprenticeship training and commitment to training provision, Economics of Education Working Paper Series, No. 0032., Institute for Strategy and Business Economics (ISU), University of Zurich.

Dustmann, C., Euwals, R., and van Soest, A. (1997) Wages in the first job after apprenticeship: movers versus stayers, Mitteilungen aus der Arbeitsmarkt- und Berufsforschung, 30, 671-4.

Dustmann, C., and Meghir, C. (2005) Wages, experience and seniority, Review of Economic Studies, 72, 77-108.

Euwals, R. and Winkelmann, R. (2004) Training intensity and first labor market outcomes of apprenticeship graduates, International Journal of Manpower, 25, 447-62.

Fitzenberger, B., Licklederer, S., and Zwiener, H. (2015) Mobility across firms and occupations among graduates from apprenticeship, Labour Economics, forthcoming.

Fitzenberger, B. and Spitz, A. (2004) Die Anatomie des Berufswechsels: eine empirische Bestandsaufnahme auf Basis der BIBB/IAB-Daten 1998/1999, Working Papers of the Research Group Heterogenous Labor 04-02, Research Group Heterogeneous Labor, University of Konstanz/ZEW Mannheim.

Gathmann, C. and Schoenberg, U. (2010) How general is human capital? A task-based approach, Journal of Labor Economics, 28, 1-49.

Geel, R., Mure, J., and Backes-Gellner, U. (2011) Specificity of occupational training and occupational mobility: an empirical study based on Lazear's skill-weights approach, Education Economics, 19, 519-35.

Gibbons, R. and Katz, L. (1991) Layoffs and lemons, Journal of Labor Economics, 9, 351-80.

Goeggel, K. and Zwick, T. (2012) Heterogeneous wage effects of apprenticeship training, Scandinavian Journal of Economics, 114, 756-79.

Harhoff, D. and Kane, T. (1997) Is the German apprenticeship system a panacea for the US labor market?, Journal of Population Economics, 10, 171-96.

Hashimoto, M. (1981) Specific human capital as a shared investment, American Economic Review, 71, 476-82.

Heckman, J. (1978) Dummy endogenous variables in a simultaneous equation system, Econometrica, 46, 931-59.

Heckman, J. (1994) Is job training oversold?, Public Interest, Spring, 91-115.

Hoeckel, K., Field, S., and Grubb, N. (2009) Switzerland. Learning for Jobs, OECD Reviews for Vocational Education and Training, Organisation for Economic Co-operation and Development, Paris.

Hoffman, N. (2011) Schooling in the Workplace: How Six of the World's Best Vocational Education Systems Prepare Young People for Jobs and Life, Harvard Education Press, Cambridge, MA.

Jovanovic, B. (1979) Job matching and the theory of turnover, Journal of Political Economy, 87, 972-90. 
Kambourov, G. and Manovskii, I. (2008) Rising occupational and industry mobility in the United States: 1968-97, International Economic Review, 49, 41-79.

Kambourov, G. and Manovskii, I. (2009) Occupational specificity of human capital, International Economic Review, 50, 63-115.

Lalé, E. (2012) Trends in occupational mobility in France: 1982-2009, Labour Economics, 19, 373-87.

Lazear, E. (2009) Firm-specific human capital: a skill-weights approach, Journal of Political Economy, 117, 914-40.

Lee, L.-F. (1983) Generalized econometric models with selectivity, Econometrica, 51, 507-12.

Leuven, E. and Oosterbeek, H. (2001) Firm-specific human capital as a shared investment: comment, American Economic Review, 91, 342-47.

Longhi, S. and Brynin, M. (2010) Occupational change in Britain and Germany, Labour Economics, 17, 655-66.

Malcomson, J., Maw, J., and McCormick, B. (2003) General training by firms, apprentice contracts, and public policy, European Economic Review, 47, 197-227.

Mortensen, D. (1986) Job search and labor market analysis, in, O., Ashenfelter and R., Layard (eds) Handbook of Labor Economics, vol. 2, North-Holland, Amsterdam.

Muehlemann, S., Wolter, S., Fuhrer, M., and Wuest, A. (2007) Lehrlingsausbildung-ökonomisch betrachtet. Ergebnisse der zweiten Kosten-Nutzen-Studie, Verlag Ruegger, Zurich.

Muehlemann, S., Pfeifer, H., Walden, G., Wenzelmann, F., and Wolter, S. (2010) The financing of apprenticeship training in the light of labor market regulations, Labour Economics, 17, 799809.

Muehlemann, S., Ryan, P., and Wolter, S. (2013) Monopsony power, pay structure and training, Industrial and Labor Relations Review, 66, 1097-114.

Neal, D. (1995) Industry-specific human capital: evidence from displaced workers, Journal of Labor Economics, 13, 653-77.

OECD. (2002) PISA 2000 Technical Report, Organisation for Economic Co-operation and Development, Paris.

OECD. (2004) Employment Outlook, Organisation for Economic Co-operation and Development, Paris.

Parrado, E., Caner, A., and Wolff, E. (2007) Occupational and industrial mobility in the United States, Labour Economics, 14, 435-55.

Rogerson, R., Shimer, R., and Wright, R. (2005) Search-theoretic models of the labor market: a survey, Journal of Economic Literature, 43, 959-88.

Schweri, J., Muehlemann, S., Pescio, Y., Walther, B., Wolter, S., and Zuercher, L. (2003) Kosten und Nutzen der Lehrlingsausbildung aus Sicht Schweizer Betriebe, Verlag Ruegger, Zurich.

Shaw, K. (1987) Occupation change, employer change, and the transferability of skills, Southern Economic Journal, 53, 702-19.

Smits, W. (2007). Industry-specific or generic skills? Conflicting interests of firms and workers, Labour Economics, 4, 653-63.

Stevens, M. (1994) A theoretical model of on-the-job training with imperfect competition, Oxford Economic Papers, 46, 537-62.

Stevens, M. (2003) Earnings functions, specific human capital, and job matching: tenure bias is negative, Journal of Labor Economics, 21, 783-805.

Stevens, M. (2004) Wage-tenure contracts in a frictional labour market: firms' strategies for recruitment and retention, Review of Economic Studies, 71, 535-51.

Sullivan, P. (2010) Empirical evidence on occupation and industry specific human capital, Labour Economics, 17, 567-80.

Symonds, W., Schwartz, R., and Ferguson, R. (2011) Pathways to Prosperity: Meeting the Challenge of Preparing Young Americans for the 21st Century. Pathways to Prosperity Project, Harvard University Graduate School of Education, Cambridge, MA. 
TREE (2008) Projekt-Dokumentation 2000-2008, TREE, Bern.

UK Parliament, corp creator (2009) Apprenticeships, Skills, Children and Learning Act 2009: Elizabeth II.

Vella, F. (1998) Estimating models with sample selection bias: a survey, Journal of Human Resources, 33, 127-69.

Vella, F. and Verbeek, M. (1999) Estimating and interpreting models with endogenous treatment effects, Journal of Business \& Economic Statistics, 17, 473-78.

Venn, D. (2009) Legislation, collective bargaining and enforcement: Updating the OECD employment protection indicators. Available at http://www.oecd.org/els/workingpapers [last accessed May 8, 2015].

von Wachter, T. and Bender, S. (2006) In the right place at the wrong time: the role of firms and luck in young workers, American Economic Review, 96, 1679-705.

Wasmer, E. (2006) General versus specific skills in labor markets with search frictions and firing costs, American Economic Review, 96, 811-31.

Weber, B., Wirz, A., and Wolter, S. (2001) Switzerland, in C., Harmon, I., Walker, and N., Westergaard-Nielsen (eds) Education and Earnings in Europe-A Cross Country Analysis of the Returns to Education, Edward Elgar, Cheltenham.

Werwatz, A. (1996) How firm-specific is German apprenticeship training?, Sonderforschungsbereich 373 Discussion Paper No. 1996-12, Humboldt Universitaet, Berlin.

Werwatz, A. (2002) Occupational mobility after apprenticeship-how effective is the German apprenticeship system?, Applied Economics Quarterly (Konjunkturpolitik), 48, 279-303.

Wolter, S. and Ryan, P. (2011) Apprenticeship, in E.A., Hanushek, S., Machin and L., Woessmann (eds) Handbook of the Economics of Education, vol. 3, Elsevier, North-Holland, Amsterdam.

Wolter, S., Muehlemann, S., and Schweri, J. (2006) Why some firms train apprentices and many others do not, German Economic Review, 7, 249-64.

Zangelidis, A. (2008) Occupational and industry specificity of human capital in the British labour market, Scottish Journal of Political Economy, 55, 420-43. 